Témoigner Témoigner. Entre histoire et mémoire

Getuigen Revue pluridisciplinaire de la Fondation Auschwitz

$126 \mid 2018$

Questions sur l'avenir du travail de mémoire

\title{
The Evolution of Holocaust Remembrance in Israeli Society
}

Les étapes de la discussion sur la Shoah dans la société israélienne

\section{Gideon Greif}

Translator. Elisabeth Tutschek

\section{(2) OpenEdition \\ Journals}

\section{Electronic version}

URL: https://journals.openedition.org/temoigner/7237

DOI: 10.4000/temoigner.7237

ISSN: 2506-6390

This article is a translation of:

Les étapes de la discussion sur la Shoah dans la société israélienne - URL : https:// journals.openedition.org/temoigner/7195 [fr]

Publisher:

Éditions du Centre d'études et de documentation Mémoire d'Auschwitz, Éditions Kimé

Printed version

Date of publication: 2 April 2018

Number of pages: 62-71

ISBN: 978-2-930953-06-9

ISSN: 2031-4183

Electronic reference

Gideon Greif, "The Evolution of Holocaust Remembrance in Israeli Society", Témoigner. Entre histoire et mémoire [Online], 126 | 2018, Online since 20 January 2022, connection on 04 February 2022. URL: http://journals.openedition.org/temoigner/7237 ; DOl: https://doi.org/10.4000/temoigner.7237 


\section{The Evolution of Holocaust Remembrance in Israeli Society}

\author{
$\rightarrow$ Gideon Greif \\ Translation from the German: \\ Elisabeth Tutschek
}

The Israeli historian and educator Gideon Greif (1951) is researcher at the Shem Olam Faith \& Holocaust Institute for Education, Documentation \& Research in Israel and at the Foundation for Holocaust Education Projects in Miami, Florida. His main research interests are the Auschwitz camp and the history of the Sonderkommando. He has published numerous articles and gives lectures around the world.

\begin{abstract}
INTRODUCTION

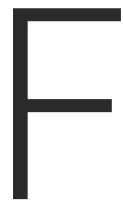

or the Jewish prisoners who lived to see the day of liberation from concentration and extermination camps, the Holocaust did not end with the capitulation of National Socialist Germany. They had to try and start a new chapter of their life - alone and full of pain and shame.

In comparison, the Jewish population of Eretz Israel ${ }^{1}$ (the so-called Yishuv) faced a set of completely different problems at that time. Because it observed things from a certain distance, the small Yishuv understood the extent of the horror that had been happening in Europe at a very late stage. Only towards the end of the war, in fact, did it start to develop compassion for the victims of the National Socialist crimes. Accusations for not having done enough to help the by-now murdered people in Europe quickly emerged. The Jewish population of Mandatory Palestine did not have a lot of time to look back, though; already in the 1940s, it would face many existential problems itself. Many years after the Holocaust, encounters with the survivors were still characterized by alienation: misunderstandings and conflicts ruled interactions with one another.

What also contributed to the alienation was the fact that the survivors, who had escaped hell and immigrated to Israel, almost immediately found themselves in another war situation. Some actually arrived in the midst of the 1948 war of independence and had to participate in battles without ever having held a weapon in their hands before. Many fell victim to the war or were seriously injured; not least because they did not understand the language of the orders, Hebrew. What is incomprehensible to us today, too, is what it must have meant for those often severly traumatized individuals to be immediately forced back to military service.
\end{abstract}

\section{DEALING WITH THE HOLOCAUST AND ITS SIGNIFICANCE FOR ISRAELI SOCIETY}

A central hypothesis, which should be questioned at this point, implies that during the first twenty years after the end of World War II, hardly any public debates about the Holocaust took place in Israel. Thumbing through history books and fiction might certainly create the impression that, in the 1940s and 1950s, this topic was almost being suppressed. ${ }^{2}$ According to this hypothesis, Isra- 
el's first prime minister, David Ben Gurion, is one of the people primarily responsible for neglecting the Nazi period; apparently, he did not show any sensitivity for the European Jews' fate at the time either (Porat 2008b, 11ff). Israeli press described the historic encounter between established Israelis and the group of immigrating survivors as hostile until the 1970s and 1980s and charachterized the entire era as a "period of silence" (Segev 1995, 251).

The idea that the Holocaust was treated as an irrelevant and tabooed topic until the turnaround that will be addressed later on, only emerged against the background of a novel Isreali identity forming following the foundation of the state, however, and, according to detailed research, it is only partly correct. In fact, the Shoah had constantly been present and had shaped Israeli society since the days before the state was founded. Both its remembrance and its direct consequences have come alive time and again in public life and have had a definite impact on Israel's society. The Holocaust repeatedly entered various debates and discussions and oftentimes led to much unrest in the community. Already in the 1940s, the memory of it was an important part of the state of Isreal's founding myth. What has changed in many ways, however, is the manner of remembrance.

The first survivors that immigrated to Eretz Israel after the end of World War II were mostly the leaders of various resistance movements. They had organized fights in the ghettos and woodlands. Among them were Ruza Korczak and Abba Kovner from Vilnius, or Zivia Lubetkin and Yitzhak Zuckerman from the Warsaw Ghetto (Porat 2008b, 114ff). They travelled the country as heroes telling their stories and published a series of books in the 1950 s. $^{3}$ Israeli society considered the revolts against the Nazis as most significant in the entire Holocaust history. They could indeed be easily linked to values of high esteem in Israel back then: national defence, fight for freedom, and state development. ${ }^{4}$

At the same time, a very negative attitude developed against the majority of European Jews, who had not resisted the Nazis and who were now disparagingly called passive, wimpy, and gutless. It was even said that the European Jews had walked "like sheep to the slaughter" (Bauer 1989, 217ff). Attributes like gutlessness or weakness contradicted the fundamental values of Israeli society at the time. This dismissive attitude towards survivors was also partly based on the feelings of guilt of that part of Israeli society, which could not come to their siblings' rescue during the Holocaust. Generally, the Holocaust was interpreted as failure - a failure of which Israel's society refused its share. ${ }^{5}$ One must understand that the Israelis at the time were experiencing a "new beginning", which was materialized in the founding of the state of Israel and resulted in a renewed confidence.

Besides the critical attitude towards survivors, sharp attacks and accusations surfaced towards "Judenräte" and other Jewish organisations that had existed during Nazi rule. This kind of criticism only faded away towards the end of the 1980s or was

(1) The territory of Israel today, before the founding of the state.

(2) For the course of historical research on the Holocaust, see Michman 2002.

(3) See for example Sefer Milhemet Hagetaot (1953, 1956), Sefer Hashomer Hatzair, Volumes 1-3 (1956), Sefer Hapartizanim Hayehudim (1959).

(4) About the role of ghetto fighters for Israel's attitude towards the Holocaust, see Cohen 2003.

(5) For the first reports on the Holocaust and reactions of the Yishuv, see Porat 2008a. 


\section{DOSSIER}

The Evolution of Holocaust Remembrance in Israeli Society (continuation)
(6) For more information on the Israeli debate concerning Judenräte and other Jewish organisations, see Michman 2011. gradually replaced by a more balanced stance. For a long time, however, shades of grey were not perceived because it was impossible to comprehend the conditions in which - and pressure under which - European Jews had to take important moral decisions. ${ }^{6}$

This tendency was reinforced by the long-lasting war of independence. Appreciation of armed battle spread and stereotypical criticisms of the alledged "passive Diaspora-Jew" intensified (Segev 1995, 244). The disparaging reports about Jews in European Displaced Persons camps for survivors of the Holocaust additionally had a negative impact - those camps were built by the Allies, in many cases on German territory. The reports conveyed a negative image of European Jews, in so far as they portrayed Jews as part of black marketing, and lacking in independence and productivity. Those prejudices were motivated by the assumption that it was impossible for the survivors in DP-camps to be reputable and virtuous since the underlying belief within Israel was that - apart from the few celebrated heroes - only corrupt, selfish, cunning, and nasty people could have survived the murdering, while the good, decent people must indeed all be dead.

The largest wave of Holocaust survivors immigrated to Israel in 1948/49, where they encountered a dominant social leitbild that condemned weakness and passivity. Traits that these people had displayed in Europe, it was assumed. As a result, their recruitment for service in the military was a particularly complex task - for the survivors themselves, it became a daily ordeal. On the one hand, they wanted to prove their spirit of resistance; on the other hand, many of them were the only ones in their family that had survived. All the more painful was that many of them, then, fell in battle: about one third of fighting soldiers in the Israeli army during the war of independence were Holocaust survivors (Yablonka 1999, 82; 1995, 557ff). Fighting together with the locals helped them, at least partly, establish feelings of belonging to the country of Israel and, in so doing, at least to some extent compensate for the traumatic event of losing family and home. Many could, from now on, look forward with new courage and renewed strength; the new state was becoming, at least in part, also their own new state. As a result, in the years that followed, many talked about transforming the feelings of revenge into a drive for reconstruction. Each new chapter in their life was considered a victory against the Nazi's plan to make the world "judenrein".

First activities, projects, and public discussions with reference to the Holocaust increased in the 1950s. They were initiated and carried out by various organisations and institutions of survivors. The survivors now exerted more pressure on the newly founded state government. The Holocaust should receive an "official" status and a central role in the public consciousness, so that survivors also felt like being part of the new society. Due to this official recognition, the survivors were no longer just on the margins of society but could act more effectively and, in this way, gained more and more political power and social influence. Quite a few survivors were part of the new parliament of Israel. Their commitment to the institutionalization 
of Holocaust remembrance led to several laws: ${ }^{7}$ on 9 August 1950, a first version of the The Law for the Judgement of the Nazis and Their Helpers became effective. ${ }^{8}$ By means of this law, Israeli tribunals later sentenced Eichmann and Demjanjuk for their crimes during the Shoah. The adoption of the The Law for the Remembrance of the Holocaust and the Martyrdom followed on 28 August 1953 and allowed the foundation of the Holocaust Memorial Yad Vashem in Israel (see also Cohen 2008). In addition, the Law concerning Anti-Nazi War-Wounded was implemented in 1954 and, on 8 April 1959, the The Law for the Remembrance Day for the Shoah and the Martyrdom was accomplished on top of it.

The 1950s were charachterized by a deep conflict that greatly polarized Israel's society. Discussions about the so-called "Wiedergutmachungsgelder" (reparations paid by the Federal Republic of Germany) and wether they should be accepted began in 1952. These discussions altogether changed the dimensions of the political discourse on the Holocaust. Prime Minister Ben Gurion had tried to reach an agreement with the Federal Republic of Germany, from which he expected badly needed economic support for his still developing country. However, large classes strongly opposed any kind of rapprochement, fearing a "gradual reconciliation" with Germany, let alone the possibility of "reparation". Concerted campaigns were organized regarding this matter and large demonstations were taking place across the country. The public opinion was preoccupied with the issue for months. Menachem Begin and his party Herut (Freedom) led the opposition, which intensively campaigned against an agreement with Germany, the main accusation being that Ben Gurion would be willing to sell the souls of murdered Jews for German money. Slogans like "Our honor will not be sold for money - our blood will not be pardoned for goods!" or "The voice of your brother's blood is crying to me from the soil!" (Genesis 4:1012) could be heard quite frequently at that time. The following question took centre stage: Does a "new Germany" really exist?"

Menachem Begin's whole life was influenced by memories of thriving Polish Jews who had been annihilated together with his family (Begin 1954, 249-252). Accordingly, the Holocaust was not merely a topic of political opportunism for him: his whole personality was connected with the traumatic experience of the extermination of European Jews. These early events, for the first time, suggested that the Holocaust had become an important part of Israel's indentity and, as such, that it had a significant impact on the public life and the shaping of politics in Israel.

In the 1950s, some trials agaist former Jewish so-called "functionary prisoners" took place as well. For the most part, it was their previous victims that had recognized defendants by chance, in the street. The trials ended quickly, though, since Israel's society was not yet ready for a differentiated view on the past (Itamar 2015, 23-40, 529-543). Any examination of dark and complex chapters, like those on functionary prisoners or even collaborations, was concluded as quickly as possible. To address the main concerns seemed more important - not those cases that were considered as secondary at the time. It was more important to commemorate the

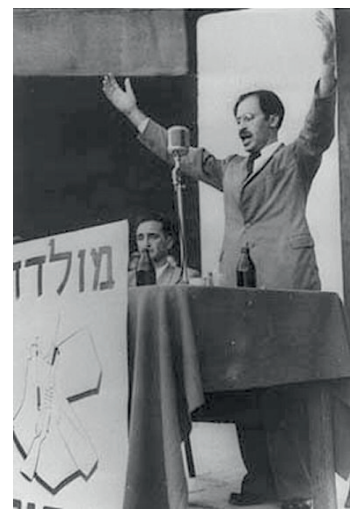

_- Menachem Begin in early August 1948, when he formed the Herut party.

(7) About the significance of legislation and courts in dealing with the Shoah, see Zertal 2005 $58 \mathrm{ff}$.

(8) It was rewritten and amended on 15 August 1963.

(9) For more information on the division of Israel's society, see Segev 1995, 257ff. 


\section{DOSSIER}

The Evolution of Holocaust Remembrance in Israeli Society (continuation) murdered and help the survivors open a new chapter in their lives, and build Israel as a home for Jews.

It can be said that until 1961, Israel's population generally did not always show sufficient patience when dealing with survivors. It did not have a "sympathetic ear" for the personal stories of individual survivors. It would be wrong to say, though, that during the first ten to fifteen years after immigration, survivors had never been given the opportunity to tell their horrible experiences. It is not correct when historiography labels this time as a "period of great silence". The experiences from the Holocaust were certainly told from time to time, but not in an autobiographic sense - rather in the form of relatively reserved and "neutral" reports. Although speaking and writing about the Holocaust was rather fiction-like in those days, it was, by all means, present as such. A more intimate level of interaction was not yet reached, so that stories continued to remain anonymous and elusive in subsequent years. Only the growing interest of society in the personal memories of survivors made it possible to help understand the Holocaust in all its dimensions.

But how can we explain the fact that collective memory remained so abstract well into the 1950s? Firstly, the long and bloody war of independence as well as the establishment of a new state had entirely claimed the mental powers of "old" and "new" Israelis. Little room was left to look at the perspective of others, especially regarding such a complex and painful history like that of the Holocaust. Secondly, there did not yet exist a distinct culture of mourning at that time. Personal grief was somewhat to be hidden. The popular motto read "Clench your teeth and push the development forward". At most, the mourning individual found comfort in the fact that they were not alone to have suffered. The repression of public grief did not only consider the victims of the Holocaust but also those of the war of independence. To look forward seemed like the most reasonable reaction, and an answer to painful times and the loss of relatives. But it prevented an adequate confrontation with any repressed grief.

The main objectives of survivors in this time were integration and assimilation (see Segev 1995, 211ff). They had to find work and a place to live, potentially finish their training or studies and, perhaps, start a family. The will to live and the wish to heal wounds were extremely strong. Repression emanated from both sides. Initially, thus, a new beginning - to live on - was essential for both sides. Not to forget that survivors were also often too ashamed to talk about their experiences, given their physical weakness, helplessness, and the torments and humiliations they had gone through. They even kept what they had witnessed from their children.

The year 1961 marked radical change as regards the attitude of Israel's society towards the Holocaust. In that year, the trial against Adolf Eichmann, the architect of the "Final Solution" to the "Jewish Question", began in Jerusalem. The effect of this trial was tremendous: it reached an enormous public through media, and the topic of the Holocaust became even more the centre of interest. For the first time, 
many Israelis heard the victims' personal stories of suffering at first hand. At that time, a well-known journalist wrote:

We knew these things, didn't we? Yes, we knew. Even before the Eichmann trial we knew. [...] But when this material was taken to the prosecution table and became part of the indictment, when these documents broke out of the silence of the archives, it was as if they were now speaking for the first time, and this knowledge was very different from that knowledge. (Haim Gouri quoted in Yablonka 2000, 180-181)

Simultaneously, a discussion flared up about the attitude towards survivors in previous years. Nathan Alterman, a famous Israeli poet, worded this transformation as follows:

Could we have given more attention to those people than we actually did? Anyway, this phase of learning has heralded a new era of dealing with the past. Criticism against Jews who suffered from the Nazi rule in Europe will not be tolerated in the future ever again. (Alterman quoted in Yablonka 2000, 181-182; translation ET)

Trial meetings were broadcasted live on the radio. Everywhere people interrupted their work and listened to the victims with tears in their eyes. The Eichmann trial shaped the coming of age of a whole generation. By its end in the year 1963, a refined awareness of the Holocaust and an improvement regarding the public image of survivors can be noticed in Israel's society.

The Eichmann trial also had an impact on scholarly and institutional work regarding the Holocaust: the Yad Vashem Institute suddenly gained in importance whereas, before the trial, it had still been relatively insignificant and unknown. In addition, research on the Holocaust became incredibly prestigious and universities started to teach the subject as well. This greatly increased its social importance. As a result, a whole generation of young Israeli historians at the time devoted their work exclusively to this topic. In doing so, the science of history underwent not only a quantitative change but also a qualitative one. Finally, the value of keeping one's human dignity, even as a mercilessly persecuted victim, was being recognized - regardless of if one had faught with a weapon in hand or not. For this insight, the term "jüdische Wehrhaftigkeit" (Jewish ability to defend oneself) was coined.10

After many years of successful integration in Israeli society, survivors now also publicly commemorated the rejection they originally encountered in Israel. They confidently stated why Israel could not readily assume the position of being a replacement for what had been lost, and stimulated a public debate about how they had been treated in the past. Remembrance of the Holocaust now opened up to a kaleidoscope of personal memories and very different individual experiences. The survivors' claim that they could not and did not want to be the average or even ideal-typical Israeli, but rather should be viewed as individuals, was increasingly getting accepted (see Porat 2008b, 356ff).
(10) For more information on the impact of the Eichmann trial, see Weitz 1996 and Segev 1995, 427ff. 


\section{DOSSIER}

The Evolution of Holocaust Remembrance in Israeli Society (continuation)
_ Hall of Names in Yad Vashem.

(11) To give an example, both the German Foreign Minister Sigmar Gabriel and the Federal President Walter Steinmeier visited the memorial within a short period of time in April 2017.

(12) Pupil's Delegations to Poland, submitted to the Knesset's Committee of Education, Culture and Sport, 29 January 2008.

(13) For more information, see the website of the campaign: http://www.operationlastchance. org/ (accessed 10 May 2017).

\section{ISRAEL'S PRACTICE OF REMEMBERING TODAY}

In the context of official memory, the Holocaust is one of the main reasons for Israel's legitimacy as a state today - since decades, in fact. To visit the Yad Vashem memorial is part of the agenda of foreign government officials. ${ }^{11}$ This means that the official memorial frequently takes centre stage not only in Israeli, but also in the global community.

The internal aim of the official practice of remembering, however, is a collective Jewish and Israeli identity. Likewise, trips of Israeli teenagers to sites of the "Final Solution to the Jewish Question" in Poland, which have become a wide phenomenon in Israel's society by now, are an integral element of the official culture of memory. These school trips to Eastern Europe show that Israel's youth is highly interested in the Holocaust. 98\% of high and vocational schools organize such trips. ${ }^{12}$ Thus, practically every student in Israel has participated in such a trip at least once.

An important concern, which had been delayed for too long, was gladly rediscovered through the activities of the Simon-Wiesenthal-Centre in Jerusalem: the prosecution of Nazi criminals. The most recent campaign (Operation: last Chance) ${ }^{13}$ tries to find Nazi criminals in those countries, where it has so far not been as easy to bring them to justice - Lithuania, Latvia, Ukraine or Poland, for example. Since hints from the general public that lead to the prosection of Nazi criminals are rewarded,

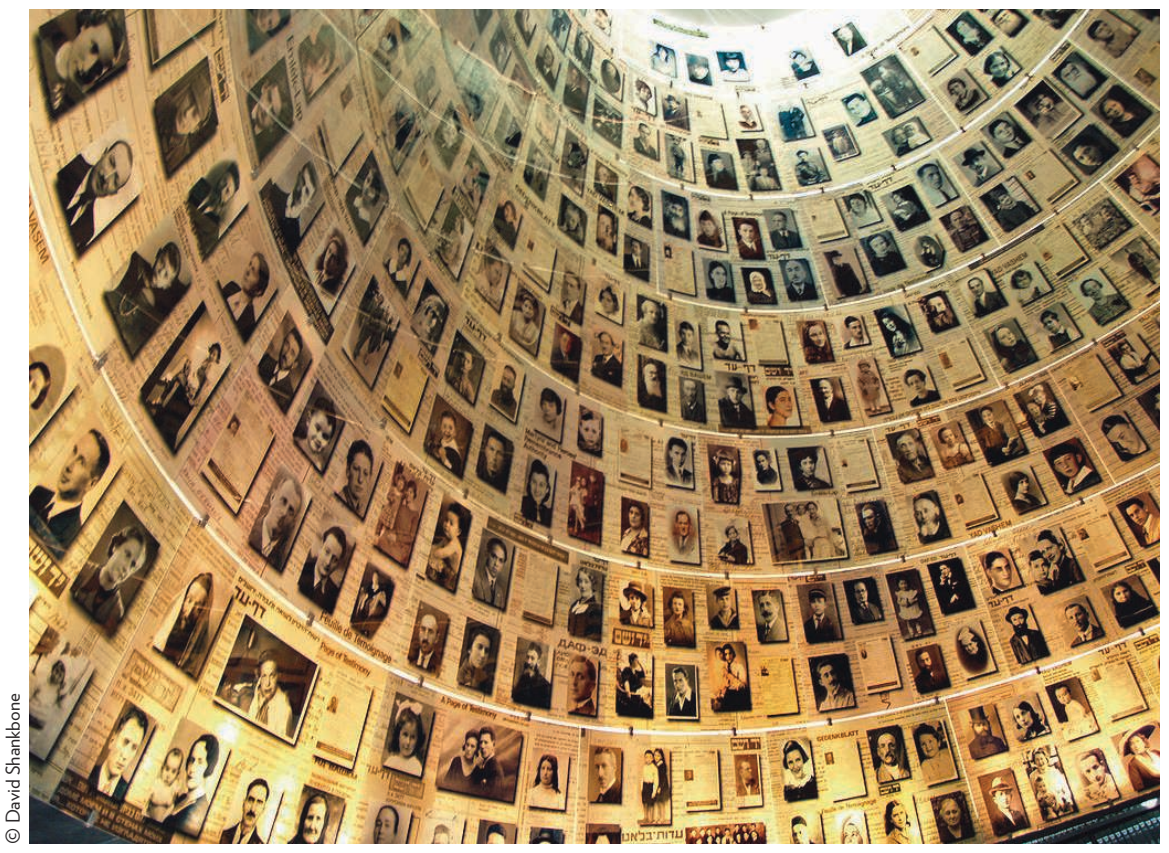


the campaign has been highly successful over the last few years and used the last opportunity to legally punish Nazi criminals.

In social debates on the Shoah, the personal stories of survivors nowadays play an ever-increasing role. Survivors have set themselves the task of visiting schools and military barracks to share their feelings and experiences with younger generations and to give them an understanding of the topic. Often, survivors accompany youth groups' visits to the sites of crime. Experiences can be authentically recounted on the spot. It is remarkable that a considerably higher number of survivors are ready to speak about their horrible past experiences today than twenty years ago. This readiness is confirmed by the many recent publications of survivors, and results from complex changes in the social attitude towards the Holocaust and its survivors. The conditions in which the Holocaust can be discussed have fundamentally and extensively changed, opening up entirely new possibilities of dealing with the past.

However, as time passes, the personal transmission of memories will not be possible much longer. Compared to the initial reluctance, now, there is a desire of survivors to leave reports about their personal experiences during the Holocaust - before it is too late. Many memorials all over the world have understood this urgency and are now trying to record the last survivors' testimonies in word, sound, and images. The Spielberg Foundation, for example, has already more than about 53,000 video recordings at its disposal by now. ${ }^{14}$ Meanwhile, elderly survivors are often being interviewed at their homes to facilitate things. And conversations with witnesses of the Holocaust at events are nowadays being recorded.

In the context of Israeli-Polish relations, the Shoah also played an important role in Israel's public space. The publications of the Jewish-Polish-American writer Jan T. Gross did not come as a surprise for a lot of Israelis. In his popular 2001 book Neighbours, Gross showed evidence that in some places it was not the Germans but their Polish neighbours who were responsible for many murders of Jews during World War II. In one instance in Jedwabne, 1600 Jews were burnt alive in a barn by Polish villagers. While Gross' discoveries were received with little surprise in Israel, the publication of the book provoked a defence reaction in Poland. Gross presented yet another book in 2006, Fear, which reports on a pogrom in Kielze when more than 40 Holocaust survivors were murdered in 1946.

While the image of Polish people has considerably deteriorated due to Gross' books, the political situation between the two countries has much improved lately. Poland has become one of Israel's closest partners and, over the last decade, always supported Isreal on the international level. Polish press almost always presents Israel in a positive light. Only the government under the Prime Minister Jaroslaw Kacznski, in power from 2006 to 2007 , briefly interrupted this process of rapprochement. The latter formed a coalition with two openly anti-Jewish, if not anti-Semitic parties, including the League of Polish Families (LPR). In addition, broadcasts of the antiSemitic Polish radio station Radio Maryja upset the relation as much as the nomination of the Minister of Education Giertych, who had expressed his disapproval of young
(14) Visit their website at http://www.vha.fu-berlin.de/ (accessed 10 May 2017) 


\section{DOSSIER}

The Evolution of Holocaust Remembrance in Israeli Society (continuation) people from Israel travelling to Poland. Afterwards, however, the relation significantly improved again (see Opielka 2007). Any developments against the background of the recent change of government remain to be seen. But what the examination of Poland's role during the Shoah shows, above all, is that any debate about the complex issues associated with the Holocaust has become easier. The perception of the historical reality is no longer as one-sided as it used to be in the beginning, and even double-edged and complex topics can become the subject of a differentiated broad social debate.

Another, more recent, event in connection with the Shoah, which very much shocked Israel's society, was the discovery that more than half of the Holocaust survivors in Israel were living under the poverty limit (see Dachs 2008). The reasons for that are the government's decades of neglect, and cases of corruption within aid organizations such as the Claims Conference. Because of huge public protests, the government announced plans to help survivors before they would die, but often it was too little or too late. Until now, not one Schekel has been disbursed. Critics fear that the government is waiting for the survivors to die. Unfortunately, it is rather an illusion than self-evidence that Holocaust survivors have a prestigious status in Israel's society. And we see that the debate about their role in the community has not come to an end until today, either.

According to statistics, about 35 to 60 Holocaust suvivors die every day (see articles in Maariv and Globs in 2011 and 2013). However, this inevitable loss is, at the same time, countered by a truly gratifying gain: the second and third generations born after the Holocaust increasingly speak of their feelings about the past. They steadily publish biographies and participate in the so-called Johrzeiten - annual commune meetings that commemorate victims. They themselves start to tell the stories of their parents as if they were their own. By doing this, they also start to explore the meaning that their parents' or grandparents' stories have for them. Many members of this generation are actually far more strongly marked by their parents' experiences than one would assume (see Wardi 1997). To a certain extent, they carry the horrors of the Holocaust within them through their identification with their families, even though in completely other ways than their parents and grandparents who have experienced the horror themselves.

And, finally: there is something extraordinary about reading print media in Israel that contributes to the impression I just outlined: not a day passes without news that is directly or indirectly related to the Holocaust. This means that the Holocaust is part of the history of Israel on the one hand, but also, that it is part of Israel's present, as pertinently discussed news in the media. The discussion about the Holocaust will thus not be closed any time soon. 


\section{WORKS CITED}

- Bauer, Yehuda, Jewish Reactions to the Holocaust, Tel Aviv, 1989.

- Begin, Menachem, 'Three Things', in Encyclopedia of Diaspora, Brisk de-Litta \& Tel Aviv, 1954, 249-252

- Cohen, Boaz, 'Holocaust Heroics. Ghetto Fighters and Partisans in Israeli Society and Historiography', Journal of Political and Military Sociology, 2003, 197-203.

- ---, 'Setting the Agenda of Holocaust Research: Discord at Yad Vashem in the 1950s', in David Bankier \& Dan Michman (eds.), Holocaust Historiography in Context. Emergences Challenges Polemics \& Achievements, Jerusalem, 2008, 255-292.

- Dachs, Gisela, 'Nach KZ und Vertreibung die Armut', Die Zeit, 24 April 2008, http://www.zeit.de/2007/43/Nach_KZ_und_Vertreibung_die (accessed 10 May 2017).

- Gross, Jan T., Neighbors. The Destruction of the Jewish Community in Jedwabne, Poland, Princeton University Press, 2001.

- ---, Fear: Anti-Semitism in Poland After Auschwitz, New York, 2006.

- Itamar, Levin, Kapo in Allenby, Jerusalem, 2015.

- Michman, Dan, Die Historiographie der Shoah aus jüdischer Sicht. Konzeptualisierungen, Terminologie, Anschauungen, Grundfragen, Hamburg, 2002.

- Michman, Dan, 'Judenräte', in Id. (ed.), Enzyklopädie jüdischer Geschichte und Kultur, vol. 3, 236-242.

- Opielka, Jan, 'Beständig gut', Jüdische Allgemeine, 1 November 2007, http://www.juedische-allgemeine.de/article/view/id/4827 (accessed 10 May 2017).

- Porat, Dina, 'First Testimonies on the Holocaust: The Problematic Nature of Conveying and Absorbing them, and the Reaction in the Yishuv', in David Bankier \& Dan Michman (eds.), Holocaust Historiography in Context. Emergences Challenges Polemics \& Achievements, Jerusalem, 2008a, 437-460.

- ---, Israeli Society, the Holocaust and its Survivors, Norfolk, 2008b.

- Sefer Hapartizanim Hayehudim, Tel Aviv, 1959.

- Sefer Hashomer Hatzair, vol. 1-3, Merhavia', 1956.

- Sefer Milhemet Hagetaot, Tel Aviv, 1953.

- Segev, Tom, Die siebte Million. Der Holocaust und Israels Politik der Erinnerung, Hamburg, 1995.

- s.n., '30 Holocaust Survivors Die Every Day in Israel', Maariv, 1 May 2011

- s.n., '37 Holocaust Survivors Die Daily in Israel', Globs, 3 April 2013.

- Wardi, Dina, Siegel der Erinnerung. Das Trauma des Holocaust Psychotherapie mit den Kindern der Überlebenden, Stuttgart, 1997.

- Weitz, Yechiam, 'The Holocaust on Trial. The Impact of the Kasztner and Eichmann Trials on Israeli Society', Israel Studies 1(2), 1996, 1-26.

- Yablonka, Hanna, 'The Silent Partner. Holocaust Survivors in the IDF', in Selwyn Ilian Troen \& Noah Lucas (eds.), Israel: The First Decade of Independence, New York, 1995, 557-572.

- ---, Survivors of the Holocaust: Israel after the War, London, 1999.

- ---, The State of Israel against Adolf Eichmann, Tel Aviv, 2000.

- Zertal, Idith, Israel's Holocaust and the Politics of Nationhood, Cambridge, 2005. 